\title{
DHA induces apoptosis of human malignant breast cancer tissues by the TLR-4/PPAR- $\alpha$ pathways
}

\author{
LIJING GENG, WEI ZHOU, BING LIU, XINYUN WANG and BO CHEN
}

Key Laboratory of Molecular Cell Biology and New Drug Development of The Educational Department of Jinzhou Province, Food Science and Engineer College, Jinzhou Medical University, Jinzhou, Liaoning 121001, P.R. China

Received August 20, 2016; Accepted September 15, 2017

DOI: $10.3892 / \mathrm{ol} .2017 .7702$

\begin{abstract}
Docosahexaenoic acid (DHA) oil is an important polyunsaturated fatty acid for the human body. Evidence has demonstrated that DHA is beneficial for inhibiting mammary carcinogenesis. However, the mechanisms of DHA mediating apoptosis induction have not been fully elucidated. Thus, in the present study, the activity levels of total-superoxide dismutase (t-SOD), catalase (CAT), glutathione-peroxidase (GSH-PX) and the concentration of malondialdehyde (MDA) were determined in DHA oil-treated human malignant breast tissues. The results revealed that compared with control, DHA significantly increased the main antioxidant enzymes levels, including t-SOD, CAT, and GSH-PX, but decreased the MDA concentration in the DHA oil treated breast cancer tissues. Furthermore, DHA significantly increased the ratio of cyclic (c)AMP/cGMP levels and promoted the expression of Toll-like receptor 4 (TLR-4) and peroxisome proliferator activated receptor (PPAR)- $\alpha$, thus DHA induced breast cancer cell apoptosis. We hypothesized that the levels of TLR-4 and PPAR- $\alpha$ are involved in the antitumorigenesis properties of DHA in breast cancer. The results of the present study hold significance for the further clinical development of DHA oil in breast cancer treatment.
\end{abstract}

\section{Introduction}

Docosahexaenoic acid (DHA; 22:6n-3) is an important member of the family of omega-3 polyunsaturated fatty acids and numerous people have added DHA oil to their daily diet $(1,2)$. Currently, breast cancer (BC) is one of the most common types of cancer among women worldwide (3). Dietary unsaturated

Correspondence to: Professor Lijing Geng, Key Laboratory of Molecular Cell Biology and New Drug Development of the Educational Department of Jinzhou Province, Food Science and Engineer College, Jinzhou Medical University, Section 3, 40 Songpo Road, Jinzhou, Liaoning 121001, P.R. China

E-mail: gengli777@126.com

Key words: docosahexaenoic acid, apoptosis, cAMP/cGMP, antioxidant enzymes, Toll-like receptor 4 , breast cancer fatty acids, particularly DHA, are considered to serve an important role in reducing the risk of developing BC (4). Certain evidence has demonstrated that DHA oil is beneficial for inhibiting mammary gland carcinogenesis (5-10). The mechanisms of DHA oil on the inhibition of tumor proliferation and the promotion of apoptosis are complex (5-10). Among the numerous key factors, oxidative stress serves an important role in the initiation, promotion, progression and apoptosis of $\mathrm{BC}$ by interfering with the intracellular signal transduction pathways, and inducing DNA damage (11). The downregulation of antioxidant enzyme (AOE) expression levels or their activities have been revealed to be associated with numerous types of cancer, including breast, prostate, bladder and hepatic cancer, and multiple myeloma (12-18). Nevertheless, other studies have reported no significant changes, higher expression or higher activity levels of AOEs in certain cancer types. For example, decreased catalase (CAT), with unchanged glutathione-peroxidase (GPH-PX) and increased levels of superoxide dismutase (SOD) levels were reported in the A549 lung cancer cell line, and lung cancer tissues (19). Therefore, maintaining the appropriate activity levels of AOEs may be essential in preventing the development of specific cancer types (20). There are specfic key AOEs with essential roles in protecting cells from oxidative stress, including SOD, CAT and GPH-PX. The regulation and increases in AOE activity are associated with cancer (12). To elucidate the anticancer mechanism of DHA in BC, antioxidant activities, including that of SOD, CAT and GSH-PX were analyzed using various assays.

The anticancer mechanisms of DHA are complex (7). Glucose uptake, glycolytic metabolism, lactate production and total glucose oxidation have been demonstrated to be significantly decreased in response to DHA supplementation, thereby decreasing oxidative metabolism, and enhancing metabolic injury (7). Furthermore, the metabolic changes in DHA led to intracellular cyclic (c)AMP and cGMP levels decreasing by $50 \%$ in MDA-MB-231, and BT-474 cancer cell lines, which mediated the phosphorylation of AMP-activated protein kinase at Thr172, a metabolic stress marker (7). It effectively provides rationale for enhancement oncurrent cancer prevention models and therapies by combining with dietary sources, including DHA oil (7).

In the present study, the tumor suppressor ratio, the activities of SOD, GSH-PX and CAT, the expression of malondialdehyde (MDA), the expression of cAMP/cGMP, and the 
expression of Toll-like receptor 4 (TLR-4) and peroxisome proliferator activated receptor (PPAR)- $\alpha$ factor were detected in human malignant $\mathrm{BC}$ tissues following treatment with DHA oil. The results aided in explaining the apoptosis mechanism of DHA on human malignant BC. The current study has clinical significance for the further development of DHA oil use in BC.

\section{Materials and methods}

Samples and reagents. DHA oil (21) (Bohai algae DHA oil, content $\sim 40 \%$ ) was provided by the Food Science and Engineering Laboratory of Jinzhou Medical University (Jinzhou, China). Human malignant BC tissue samples were provided by the First Affiliated Hospital of Jinzhou Medical University. The approval of removed tissues for research purposes was obtained from the Ethics Committee of The First Affiliated Hospital of Jinzhou Medical University. Written informed consent was obtained from each patient.

Hydrocortison (1 gram) was purchased from Sigma-Aldrich (Merck KGaA, Darmstadt, Germany). Anti-TLR4 antibody produced in rabbit (100 $\mu \mathrm{g})$ was purchased from Sigm-Aldrich (Merck KGaA). Anti-PPARa rabbit antibody $(100 \mu \mathrm{g})$ was purchased from Abcam (Cambridge, UK). Horseradish peroxidase (HRP)-conjugated sheep anti-rabbit IgG H\&L (1 mg) was purchased from Abcam. Trypsin, Hanks, RPMI-1640 medium and Dulbecco's modified Eagle's medium (DMEM) was purchased from Gibco (Thermo Fisher Scientific, Inc., Waltham, MA, USA). The $10 \%$ fetal bovine serum and $10 \%$ normal goat serum was purchased from Hyclone (GE Healthcare Life Sciences, Logan, UT, USA). Tris-buffered saline ( $\mathrm{pH} 7.6$; cat. no. SG EC-925) was purchased from Shanghai Sango Biotechnology Co. Ltd. (Shanghai, China). Other reagents were analytical solvents and purchased from Hongda Co. (Jinzhou, China; https://0ds13046577.atobo.com.cn/).

Human malignant BC tissue culture. Human malignant BC tissues were obtained from the Breast Surgery Department of the First Affiliated Hospital of Jinzhou Medical University. The BC tissues were sterilized with $75 \%$ alcohol for 2 min and then washed three times with RPMI-1640. The BC tissues were sliced into small pieces of 1-2 $\mathrm{mm}^{3}$. Each BC tissue sample was cultured in RPMI-1640 medium with or without DHA oil. One of BC tissue samples was used as a control (control group) and the rest were treated with DHA oil ( 40\%) with final DHA concentrations of $100 \mu \mathrm{g} / \mathrm{ml}$ (first group), $150 \mu \mathrm{g} / \mathrm{ml}$ (second group) and $200 \mu \mathrm{g} / \mathrm{ml}$ (third group). Each group contained three samples of BC tissues. Each individual BC was placed in a $3.5-\mathrm{cm}$ culture well. All wells were cultured for $24 \mathrm{~h}$ with $5 \% \mathrm{CO}_{2}$ at $37^{\circ} \mathrm{C}$.

After being cultured with or without DHA for $24 \mathrm{~h}$, the $\mathrm{BC}$ tissues were embedded in paraffin to observe the effect of DHA oil on the morphology of BC. Five random sections were obtained from each sample. For research on the signal transduction pathway of DHA, BC tissues were cultured for $24 \mathrm{~h}$ in RPMI-1640 medium with or without DHA oil, and then the total protein was extracted from the BC tissues. The total protein content was used to detect the effect of DHA on BC antioxidant activities. Each sample was measured three times in parallel.
Histological observation. For hematoxylin-eosin (H.E.) staining, sections were rinsed in double distilled water and were incubated with hematoxylin solution stain for $5 \mathrm{~min}$ at $25^{\circ} \mathrm{C}$. After $5 \mathrm{~min}$, sections were washed with running tap water, sequentially followed by differentiation for $30 \mathrm{sec}$ in $1 \%$ acid-alcohol (hydrochloric acid and ethanol) at $25^{\circ} \mathrm{C}$ and then washed for 1 min again with running tap water. Subsequently, all sections were stained with eosin for $30 \mathrm{sec}$ and then dehydrated with different concentrations alcohol (70,80, 90 and 100\%) for 2 min each. Sections were covered with xylene-based mounting medium, after two changes of xylene for $5 \mathrm{~min}$ each time at $25^{\circ} \mathrm{C}$. The effect of DHA on the H.E. BC sections was observed using an inverted microscope (OLYMPUS, IX73+DP73, 12V $100 \mathrm{~W}$ halogen lamp). Analysis of the tissue areas occupied was performed using Image Pro 5.0 Plus software (Media Cybernetics, Inc., Rockville, MD, USA). Suppressor ratio $(\%)=(\mathrm{DHA}$ treatment group entity tissue area-the control group entity tissue area)/control group entity tissue area $\mathrm{x} 100 \%$.

\section{Effect of DHA on the antioxidant activities of BC tissues}

Detection of the activities of antioxidant enzymes. The $\mathrm{BC}$ tissues were centrifuged at $1,500 \mathrm{x} \mathrm{g}$ for $15 \mathrm{~min}$ at $4^{\circ} \mathrm{C}$ to remove the debris following homogenizing with normal saline solution $(0.9 \%$ sodium chloride). The supernatant was transferred into new tubes for the evaluation of the SOD, CAT and GSH-PX activities. The measurements were performed following the manufacturer's protocol of an assay kit (SOD: cat. no. A001-1; CAT: cat. no. A007-2; GSH-PX: cat. no. A005; Nanjing KeyGen Biotech Co., Ltd., Nanjing, China).

SOD activities were determined (at $550 \mathrm{~nm}$ ) using the Xanthine oxidase method and expressed as nU/mg protein (22). CAT was measured by the reaction of CAT scavenging $\mathrm{H}_{2} \mathrm{O}_{2}$, and ammonium molybdate was added to generate a pale yellow complex (maximum absorption peak at $405 \mathrm{~nm}$ ). CAT activities were expressed as $\mathrm{mU} / \mathrm{mg}$ protein (23). GSH-PX was reacted with dithiobis-nitrobenzoic acid to produce a yellow compound, 5-dithio-bis2-nitrobenzoic acid dithiobis-nitrobenzoic acid anion (maximum absorption peak at $420 \mathrm{~nm}$ ). The concentrations of GSH-PX were expressed as nU/mg protein (24).

Detection of MDA content. Fatty-acid peroxidation MDA content in the homogenate $(0.1 \mathrm{ml})$ was measured using the thiobarbituric acid (TBA) method according to the manufacturer's protocol (cat. no. A003-1; Nanjing KeyGen Biotech Co., Ltd.). MDA and TBA condensate to produce a red product (maximum absorption peak at $532 \mathrm{~nm}$ ). Thus, the MDA content was calculated by measuring the $532 \mathrm{~nm}$ absorbance and expressed as nmol/mg protein $(23,24)$.

cAMP and cGMP assays. The cAMP and cGMP content of BC tissues were determined following the manufacturer's protocol (cAMP: cat. no. 80204; cGMP: cat. no. 80104; Neweast Biotech Company, Wuhan, China) by ELISA. The cAMP and cGMP extracts were diluted (1:10) with sample diluent. Optical densities were measured at $450 \mathrm{~nm}(25,26)$.

Immunohistochemistry. The expression of TLR-4 factor was measured by immunohistochemistry. Briefly, 4- $\mu \mathrm{m}$ thick sections were deparaffinized and the endogenous peroxidase activity was blocked for $10 \mathrm{~min}$ with $3 \%$ hydrogen peroxide at 
Table I. Description of all experimental multiple comparison results.

Multiple comparison

Figure $\quad$ Group (DHA oil concentration, $\mu \mathrm{g} / \mathrm{ml}$ )

$\alpha=0.05 \quad \alpha=0.01$

Fig. 1E

0

Fig. 1F

100

150

200

Fig. 2A

0

100

150

200

Fig. 2B

0

100

150

200

Fig. 2C

0

100

150

200

Fig. 2D

0

100

150

200

Fig. 2E

0

100

150

200

Fig. 2F

0

100

150

200

Fig. 3F

0

100

150

200

Fig. 3G

0

100

150

200 a

$a b$

bc

c

b

$a b$

a

d

c

b

a

d

c

b

a

d

c

b

a

a

b

c

d

d

c

b

a

d

c

b

a

b

a

a

b

b

b

b

a
A

AB

B

B

A

A

A

D

C

B

A

D

C

B

A

D

C

B

A

A

B

C

D

D

C

B

A

D

C

B

A

B

A

A

B

B

B

B

A $25^{\circ} \mathrm{C}$. Subsequently, sections were treated for $30 \mathrm{~min}$ with $10 \%$ normal goat serum in Tris-buffered saline $(\mathrm{pH}=7.6)$ at $37^{\circ} \mathrm{C}$. Then, sections were incubated with monoclonal anti-TLR4 rabbit antibody (1:200; cat. no. PRS3141-100UG) overnight at $4^{\circ} \mathrm{C}$. After washing three times with PBS, they were incubated with the HRP-sheep anti-rabbit IgG H\&L secondary antibody (1:500; cat. no. ab6721) at room temperature for $1 \mathrm{~h}$, followed by incubation with the color reagent 3,3'-diaminobenzidine for $3 \mathrm{~min}$ at $25^{\circ} \mathrm{C}(26)$. Analysis of the average gray density value (GDV) of TLR-4 was performed using Image Pro 5.0 Plus software.

Western blotting. All BC tissues were stored within liquid nitrogen prior to protein extraction. Briefly, tissues were 
homogenized with $0.5 \mathrm{ml}$ ice-cold lysis buffer $(\mathrm{pH} 7.5,20 \mathrm{mM}$ Tris- $\mathrm{HCl}, 1 \mathrm{mM}$ EDTA, $1 \mathrm{mM}$ DTT, $5 \mathrm{mM} \mathrm{MgCl}_{2}, 20 \mu \mathrm{g} / \mathrm{ml}$ aprotinin, $2 \mathrm{mM}$ sodium orthovanadate and $1 \mathrm{mM}$ PMSF). The homogenates were centrifuged at $10,000 \mathrm{xg}$ at $4^{\circ} \mathrm{C}$ for $20 \mathrm{~min}$ and the supernatant was removed. The protein concentration was determined using the bicinchoninic acid method with bovine serum albumin as the standard. Samples $(30 \mu \mathrm{g} / \mathrm{ml}$ protein per lane) were boiled for $5 \mathrm{~min}$, separated using $15 \%$ SDS-PAGE and transferred onto a nitrocellulose membrane (EMD Millipore, Billerica, MA, USA). Subsequently, membranes were blocked with 5\% bovine serum albumin at room temperature for $1.5 \mathrm{~h}$ and incubated with the anti-PPAR $\alpha$ rabbit antibody $\left(1: 1,000\right.$; cat. no. ab8934) at $4^{\circ} \mathrm{C}$ for $12 \mathrm{~h}$. The membrane was then washed three times with TBS Tween 20 buffer and incubated with the secondary HRP-conjugated sheep anti-rabbit IgG H\&L antibody (1:200; cat. no. ab6721) at room temperature for $1 \mathrm{~h}$. The GDV of specific bands was measured with Quantity One version 4.62 software (Bio-Rad Laboratories, Inc., Hercules, CA, USA) (27).

Statistical analysis. Each experiment was performed in parallel three times. All data are expressed as the mean \pm standard deviation. Statistical analysis was performed using one-way analysis of variance and was analyzed further by Tukey's honest significant difference test (28). Different lowercase letters in the same column represent significant differences at $\mathrm{P} \leq 0.05$ and different capital letters represent significant differences at $\mathrm{P} \leq 0.01$. All data analyses were conducted using SPSS 19.0 software (IBM Corp., Armonk, NY, USA).

\section{Results}

Effects of DHA on BC morphology and the suppressor ratio of DHA in BC. From the results of paraffin sections (H.E. staining), as DHA oil concentration increased, the morphology of BC cells became more irregular. For example, apoptosis of $\mathrm{BC}$ cells was more evident compared with the control group (Fig. 1A). The surrounding of tissues appeared to be shedding, phagocytized and the cell connections had disappeared (Fig. 1B). There were more vesicles observed within cells (Fig. 1C). The overall volume of BC cells had shrunk, whereas the cytoplasmic density of BC cells had increased. Chromatin agglutination occurred, and the nuclear membrane and nucleolus were broken or absent (Fig. 1D).

In Fig. 1E, the area sizes of human malignant breast tissues in the $150 \mu \mathrm{g} / \mathrm{ml}$ DHA group were significantly reduced compared with the control ( $0 \mu \mathrm{g} / \mathrm{ml}$ DHA group). The suppressor ratio of DHA in the $200 \mu \mathrm{g} / \mathrm{ml}$ DHA group was significantly higher compared with the ratio of the $100 \mu \mathrm{g} / \mathrm{ml}$ DHA group (Fig. 1F).

Effect of DHA on the activities of AOEs. The activities of $\mathrm{t}-\mathrm{SOD}, \mathrm{CAT}$ and GSH-PX in the BC tissues increased in a DHA dose-dependent manner. Compared with the control group (500.33 $\pm 23.20 \mathrm{nU} / \mathrm{mg}$ protein), the activities of SOD was significantly enhanced by $22.4 \%$ in the $100 \mu \mathrm{g} / \mathrm{ml}$ DHA group $(612.37 \pm 14.98 \mathrm{nU} / \mathrm{mg}$ protein; $\mathrm{P}<0.001)$ and reached the maximum at $79.24 \%$ in the $200 \mu \mathrm{g} / \mathrm{ml}$ DHA group $(896.78 \pm 38.87 \mathrm{nU} / \mathrm{mg}$ protein; $\mathrm{P}<0.001$; Fig. $2 \mathrm{~A})$.
Compared with the control group $(1.59 \pm 0.06 \mathrm{mU} / \mathrm{mg}$ protein), the activities of CAT was enhanced by $14.44 \%$ the $100 \mu \mathrm{g} / \mathrm{ml}$ DHA group $(1.82 \pm 0.05 \mathrm{mU} / \mathrm{mg}$ protein; $\mathrm{P}<0.001)$ and reached the maximum at $38.30 \%$ in the $200 \mu \mathrm{g} / \mathrm{ml}$ DHA group (2.20 $\pm 0.14 \mathrm{mU} / \mathrm{mg}$ protein; $\mathrm{P}<0.001$; Fig. $2 \mathrm{~B})$.

Compared with the control group $(104.91 \pm 3.51 \mathrm{mU} / \mathrm{mg}$ protein), the activity of GSH-PX was enhanced by $37.75 \%$ in the $100 \mu \mathrm{g} / \mathrm{ml}$ DHA group $(144.51 \pm 3.95 \mathrm{mU} / \mathrm{mg}$ protein; $\mathrm{P}<0.001)$ and reached the maximum at $100.17 \%$ in the $200 \mu \mathrm{g} / \mathrm{ml}$ DHA group $(210.00 \pm 6.01 \mathrm{mU} / \mathrm{mg}$ protein; $\mathrm{P}<0.001$; Fig. $2 \mathrm{C})$.

Effect of DHA on the concentration of MDA in the BC tissues. In Fig. 2D, the MDA concentration of BC tissues was significantly reduced compared with the control. Compared with the control group $(122.49 \pm 5.15 \mathrm{nmol} / \mathrm{mg}$ protein), the mean MDA concentration in the $100 \mu \mathrm{g} / \mathrm{ml}$ DHA group $(102.31 \pm 8.49 \mathrm{nmol} / \mathrm{mg}$ protein) was significantly decreased by $16.48 \%(\mathrm{P}<0.001)$ and in the $200 \mu \mathrm{g} / \mathrm{ml}$ DHA group was decreased by $52.22 \%(63.96 \pm 5.24 \mathrm{nmol} / \mathrm{mg}$ protein; $\mathrm{P}<0.001)$.

DHA serves as a death receptor via the upregulation of cancer-specific cAMP/cGMP. Intracellular cAMP and cGMP are the secondary messengers involved in the generation of $\mathrm{BC}$. The levels of cAMP and cGMP of the BC tissues with DHA treatment were significantly higher compared with the control groups (Fig. 2E and F).

Compared with the control group $(0.50 \pm 0.062 \mathrm{nmol} / \mathrm{mg})$, the mean concentration of cAMP in the $100 \mu \mathrm{g} / \mathrm{ml}$ DHA group $(0.73 \pm 0.043 \mathrm{nmol} / \mathrm{mg} ; \mathrm{P}<0.001)$ significantly increased by $44.78 \%$ and reached the maximum at $246.77 \%$ in the $200 \mu \mathrm{g} / \mathrm{ml}$ DHA group $(1.74 \pm 0.056 \mathrm{nmol} / \mathrm{mg}$; $\mathrm{P}<0.001)$. Compared with the 100 and $150 \mu \mathrm{g} / \mathrm{ml}$ DHA group $(0.73 \pm 0.043$ and $1.10 \pm 0.053 \mathrm{nmol} / \mathrm{mg}$, respectively), the mean concentration of cAMP in the $200 \mu \mathrm{g} / \mathrm{ml}$ DHA group was significantly increased by 139.52 , and $59.13 \%$, respectively (Fig. 2E).

Compared with the control group $(54.50 \pm 1.42 \mathrm{~m} \mathrm{nmol} / \mathrm{mg})$, the mean concentration of cGMP in the $100 \mu \mathrm{g} / \mathrm{ml}$ DHA group $(62.01 \pm 1.41 \mathrm{nmol} / \mathrm{mg} ; \mathrm{P}<0.001)$ significantly increased by $13.79 \%$ and reached the maximum at $79.64 \%$ in the $200 \mu \mathrm{g} / \mathrm{ml}$ DHA group $(97.89 \pm 1.78 \mathrm{nmol} / \mathrm{mg} ; \mathrm{P}<0.001)$. Compared with the 100 and $150 \mu \mathrm{g} / \mathrm{ml}$ DHA group $(62.01 \pm 1.41$ and $74.32 \pm 1.27 \mathrm{nmol} / \mathrm{mg}$, respectively), the mean concentration of cGMP in the $200 \mu \mathrm{g} / \mathrm{ml}$ DHA group significantly increased by 57.87 , and $31.72 \%$ respectively (Fig. 2 F).

Compared with the control group, the $200 \mu \mathrm{g} / \mathrm{ml}$ DHA group revealed significantly higher concentrations of cAMP/cGMP with a 2-fold increase (Fig. 2G).

Effect of DHA on the expression and localization of TLR-4 factor by immunohistochemistry. The immunohistochemical staining of the control group (Fig. 3) was brown in the cell membrane and cytoplasm. The GDV of TLR-4 showed that TLR-4 mainly existed in the cell membrane and cytoplasm (Fig. 3A-D and F). The results revealed that there was TLR-4 expression in the immunohistochemistry sections of breast cancer tissues (Fig. 3A and F), thus TLR-4 may participate in the generation of $\mathrm{BC}$ and localized primarily in the membrane and cytoplasm of BC cells. When DHA was added at $100 \mu \mathrm{g} / \mathrm{ml}$ (Fig. 3B), TLR-4 expression reached the maximum (Fig. 3F); 

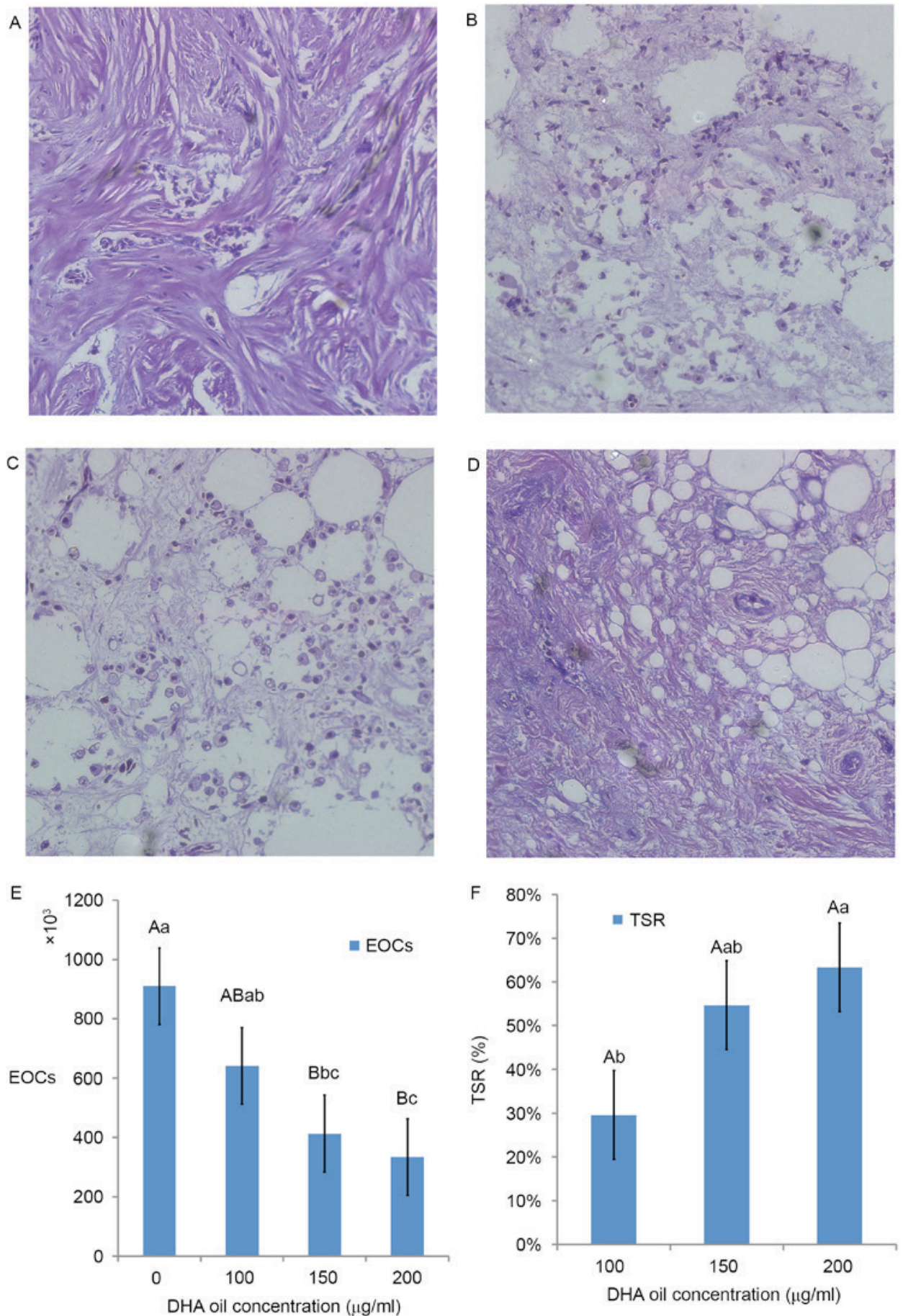

Figure 1. Hematoxylin and eosin staining of human malignant breast cancer tissues following DHA oil treatment for 1 day. Representative images of the (A) control group, (B) $100 \mu \mathrm{g} / \mathrm{ml}$ DHA group, (C) $150 \mu \mathrm{g} / \mathrm{ml}$ DHA group and (D) $200 \mu \mathrm{g} / \mathrm{ml}$ DHA group. Magnification, x200. Effect of DHA on the (E) area sizes and (F) the tumor suppression ratios of human malignant breast tissues. The results are expressed as the mean \pm standard deviation. Different lowercase and uppercase letters indicate the significance of multiple comparisons tests of the results. Different lowercase letters in the same column represent significance differences at $\mathrm{P} \leq 0.05$ and different capital letters represent significant differences at $\mathrm{P} \leq 0.01$ (Table I). EOCs, entity organization areas; DHA, docosahexaenoic acid; TSR, tumor suppression ratio.

however, the expression of TLR-4 in the $200 \mu \mathrm{g} / \mathrm{ml}$ (Fig. 3D) DHA group was similar to that of the control group ( $P>0.05$, Fig. 3F). The expression of TLR-4 in the $150 \mu \mathrm{g} / \mathrm{ml}$ (Fig. 3C) DHA group was similar to the $100 \mu \mathrm{g} / \mathrm{ml}$ DHA group (Fig. 3B; $\mathrm{P}>0.05$, Fig. 3F).

Effect of DHA on the expression of PPAR- $\alpha$ by western blotting. The western blotting result (Fig. 3E) and the GDV
(Fig. 3G) of the control group bands revealed that PPAR- $\alpha$ protein expressed in breast cancer tissue. The results revealed that PPAR- $\alpha$ participated in the generation of BC in Fig. 3E and $\mathrm{G}$. The expression of PPAR- $\alpha$ in BC tissues increased with DHA and reached the maximum in the $200 \mu \mathrm{g} / \mathrm{ml}$ DHA group (Fig. 3E; P<0.01; Fig. 3G). The expression of PPAR- $\alpha$ in the control group, $100 \mu \mathrm{g} / \mathrm{ml}$ DHA group and $150 \mu \mathrm{g} / \mathrm{ml}$ DHA group are similar (Fig. 3E; P>0.05). 

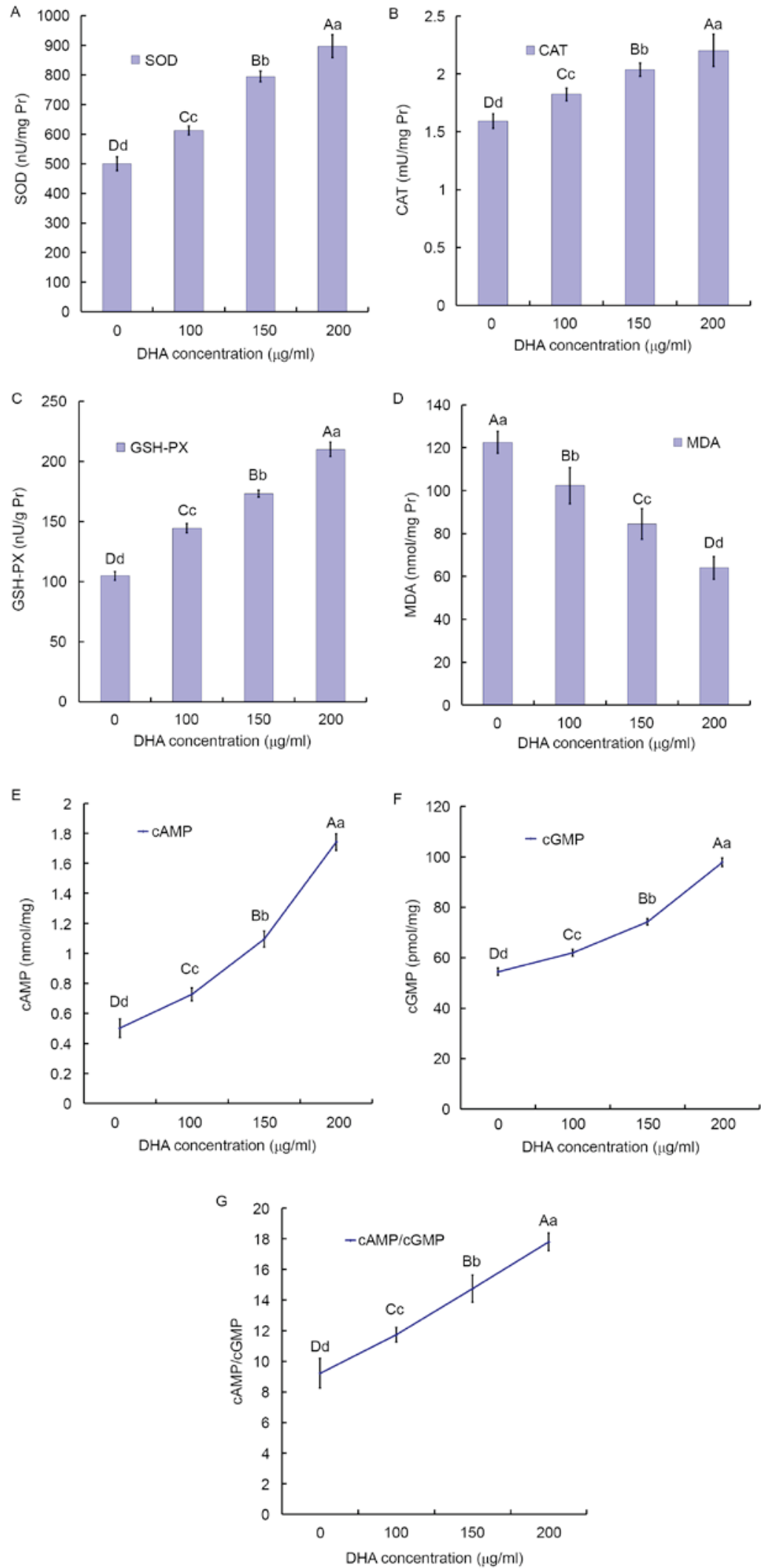

Figure 2. Effect of DHA on the activity of antioxidant enzymes and secondary messengers. (A) SOD, (B) GSH-PX and (C) CAT activities, and (D) MDA concentration in the BCTs incubated for $24 \mathrm{~h}$ with increasing concentrations of DHA. The results are expressed as the mean \pm standard deviation of four independent experiments, two samples per experiment performed in triplicate. The homogeneity of variance comparisons were analyzed using SPSS 19.0 software. Statistical analysis was analyzed by Tukey's honest significant difference test following one-way analysis of variance. Different lowercase letters in the same column represent significant differences at $\mathrm{P} \leq 0.05$ and different capital letters represent significant differences at $\mathrm{P} \leq 0.01$, but not significantly different $(\mathrm{P}>0.05)$ for the same letter (Table I). DHA serves as a death receptor via cancer-specific cAMP/cGMP upregulation. Effects of DHA on (E) cAMP and (F) cGMP levels in the BCTs following $24 \mathrm{~h}$. (G) Effects of DHA on the ratio of cAMP/cGMP levels in the BCTs following $24 \mathrm{~h}$. Different lowercase and uppercase letters indicate the significance of multiple comparisons tests of the results. Different lowercase letters in the same column represent significance differences at $\mathrm{P} \leq 0.05$ and different capital letters represent significant differences at $\mathrm{P} \leq 0.01$ (Table I). SOD, super oxide dismutase; DHA, docosahexaenoic acid; CAT, catalase; GSH-PX, glutathione-peroxidase; MDA, malondialdehyde; cAMP, cyclic AMP; cGMP, cyclic GMP; BCTs, breast cancer tissues. 
A

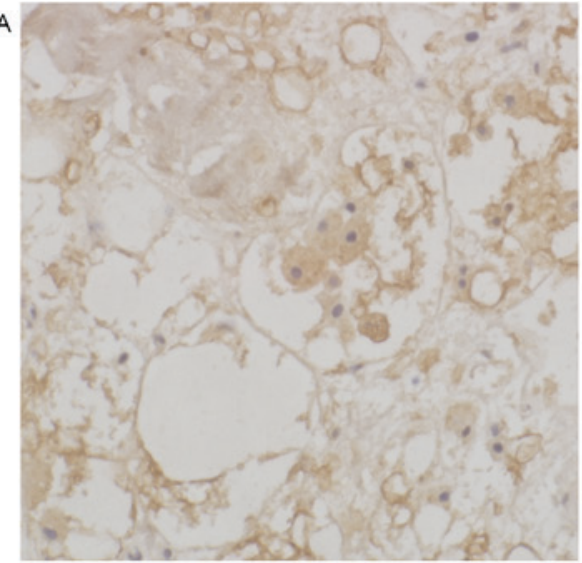

C

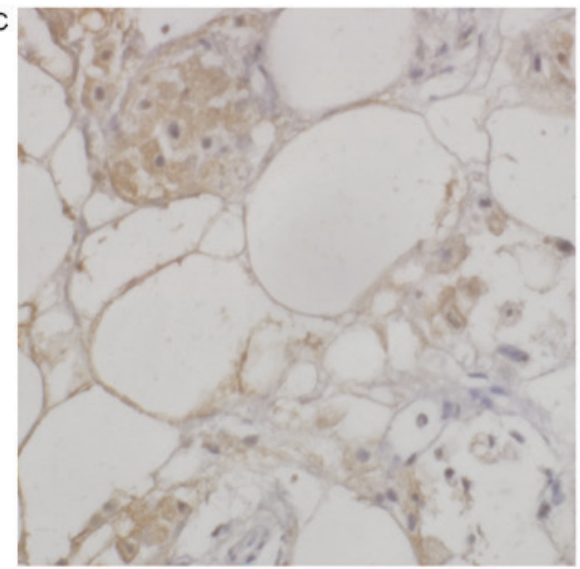

B

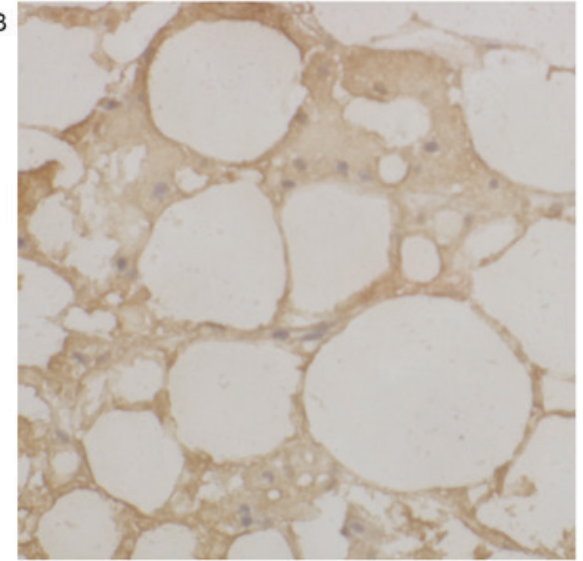

D

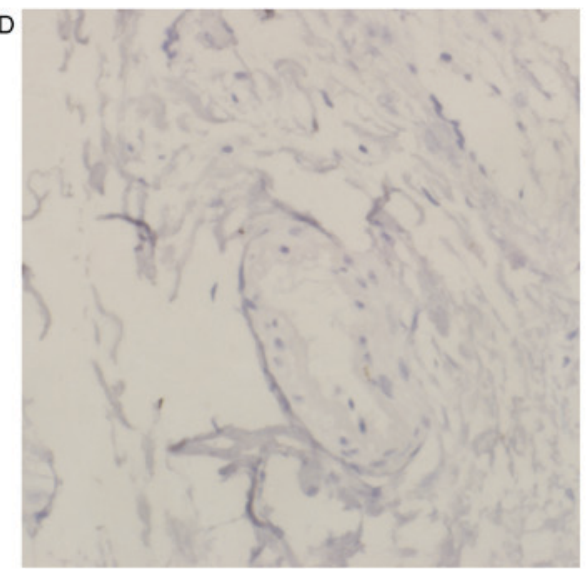

\section{$\mathrm{DHA}(\mu \mathrm{g} / \mathrm{ml})$}

0

100

150

200

PPAR- $\alpha$

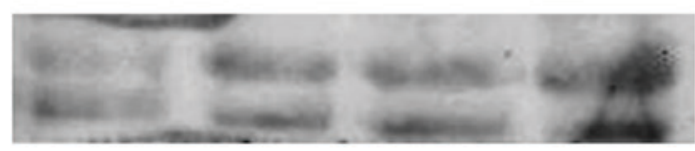

\section{$\beta$-actin}
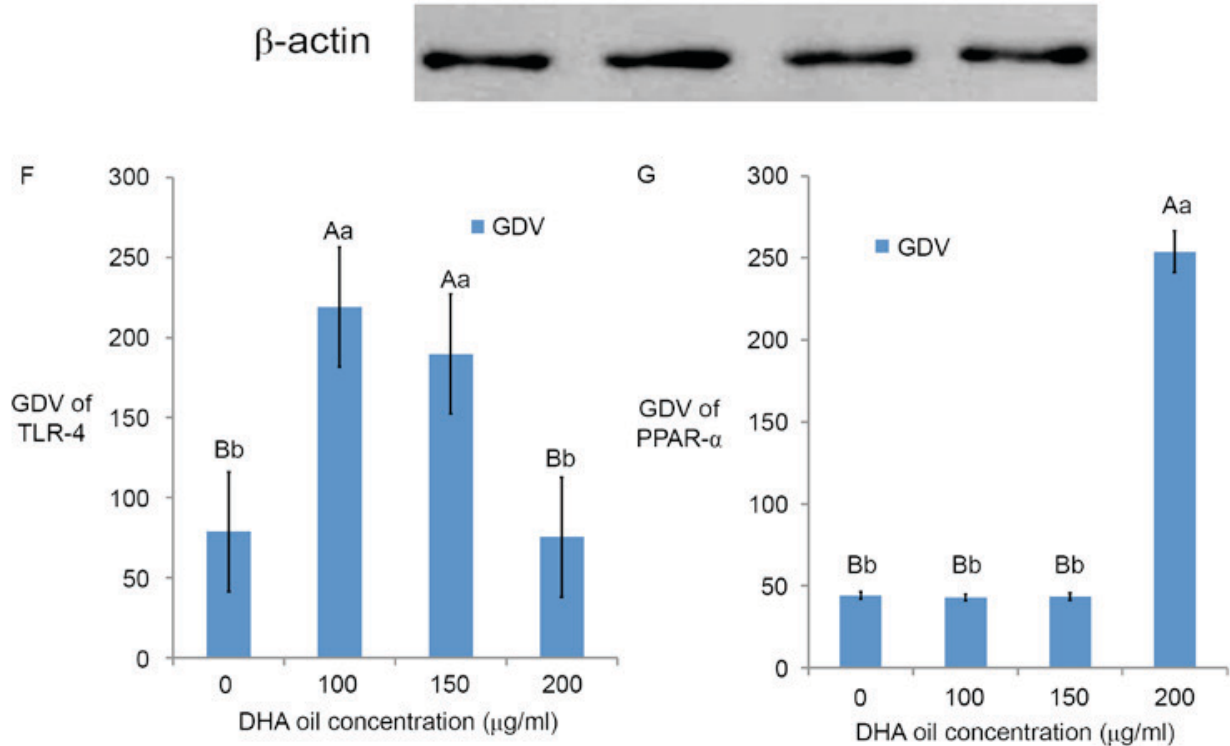

Figure 3. Effect of DHA on the signaling molecules in breast cancer. Immunohistochemical results of TLR-4 in breast cancer: (A) Control, (B) $100 \mu \mathrm{g} / \mathrm{ml} \mathrm{DHA}$ group, (C) $150 \mu \mathrm{g} / \mathrm{ml}$ DHA group and (D) $200 \mu \mathrm{g} / \mathrm{ml}$ DHA group. Magnification, x400. (E) Western blotting results of PPAR- $\alpha$. The GDV of (F) TLR-4- and (G) PPAR- $\alpha$-positive expression areas in different groups. The results are expressed as the mean \pm standard deviation. Different lowercase and uppercase letters indicate the significance of multiple comparisons tests of the results. Different lowercase letters in the same column represent significance differences at $\mathrm{P} \leq 0.05$ and different capital letters represent significant differences at $\mathrm{P} \leq 0.01$ (Table I). DHA, docosahexaenoic acid; PPAR, peroxisome proliferator activated receptor; GDV, gray density value; TLR-4, Toll-like receptor 4. 


\section{Discussion}

The results of the H.E. staining in the present study demonstrated that DHA oil induced the apoptosis of BC cells. The suppressor ratio of DHA treatment revealed that DHA significantly inhibited the growth and induced the apoptosis of $\mathrm{BC}$ cells.

Oxidative stress is the most important cause of cell damage, leading to the occurrence and development of cardiovascular disease. AOEs protect cells from free radicals and oxidative stress, contributing to the prevention of cancer. Numerous studies have reported that the upregulated expression or higher activity of AOEs may be used as effective strategies for cancer prevention and therapy. For example, MRN-100, as an adjuvant therapy was demonstrated to be effective in the treatment of esophageal/gastric carcinoma, exerting an antioxidant effect in the stomach and blood tissues by increasing the levels of GSH-PX, SOD, CAT, GSH-PX, and the total antioxidant capacity (29). Ganoderma lucidum significantly enhanced the levels of SOD, CAT and GPH-PX in the plasma, liver, and mammary tissues, thus being an effective chemopreventive agent against BC (30). Tangeretin increased the levels of AOEs, including SOD, CAT, GST and GSH-PX significantly, indicating to be effective, and efficient for the treatment of $\mathrm{BC}(31)$.

SOD is a class of AOEs that catalyzes the dismutation of superoxide radicals into $\mathrm{H}_{2} \mathrm{O}_{2}$ and $\mathrm{O}_{2}$. Subsequently, CAT and GSH-PX catalyze $\mathrm{H}_{2} \mathrm{O}_{2}$ decomposition to $\mathrm{H}_{2} \mathrm{O}$ and $\mathrm{O}_{2}(20)$. $\mathrm{H}_{2} \mathrm{O}_{2}$ is not only a reactive oxygen species, but also a major signaling molecule (32). Multiple studies have indicated that mitochondrial $\mathrm{H}_{2} \mathrm{O}_{2}$ is a direct and effective apoptosis inducer $(32,33)$. The present study demonstrated that DHA was able to simultaneously upregulate the expression levels and activities of SOD, CAT, and GSH-PX in BC tissues. Therefore, DHA may inhibit the proliferation of BC cells and the associated oxidative stress mechanism.

Oxidative stress produces fatty-acid peroxidation whose metabolites possess high toxicities and mutagenic properties (34). The main fatty-acid peroxidation is MDA (34). The results in the current study revealed that DHA significantly decreased the MDA concentration of BC tissues.

The cyclic nucleotides cAMP and cGMP have been recognized as important signaling molecules within cells. Under normal physiological conditions, cyclic nucleotides regulate a myriad of biological processes. In addition, altered cyclic nucleotide signaling has been observed in a number of pathophysiological conditions, including cancer. Several studies have demonstrated that activation of cyclic nucleotide signaling leads to the inhibition of proliferation and activation of apoptosis in numerous types of cancer cells, such as bladder $(35,36)$, breast (37-41), colon (42-44), hepatoma (45), leukemia $(46,47)$, lung $(36,48)$, lymphoma $(49,50)$, ovarian $(36,51)$, pituitary $(52)$, prostate (36) and skin cancer (53). In the present study, the results demonstrated that DHA produced significant increase in the ratio of $\mathrm{cAMP} / \mathrm{cGMP}$ levels $(\mathrm{P}<0.001)$, suggesting that DHA inhibits the proliferation and induces apoptosis of $\mathrm{BC}$ cells by increasing the ratio of cAMP/cGMP.

Increasing evidence suggests an association between chronic inflammation and cancer development (54). Recent evidence suggests that inflammation and oxidative stress play

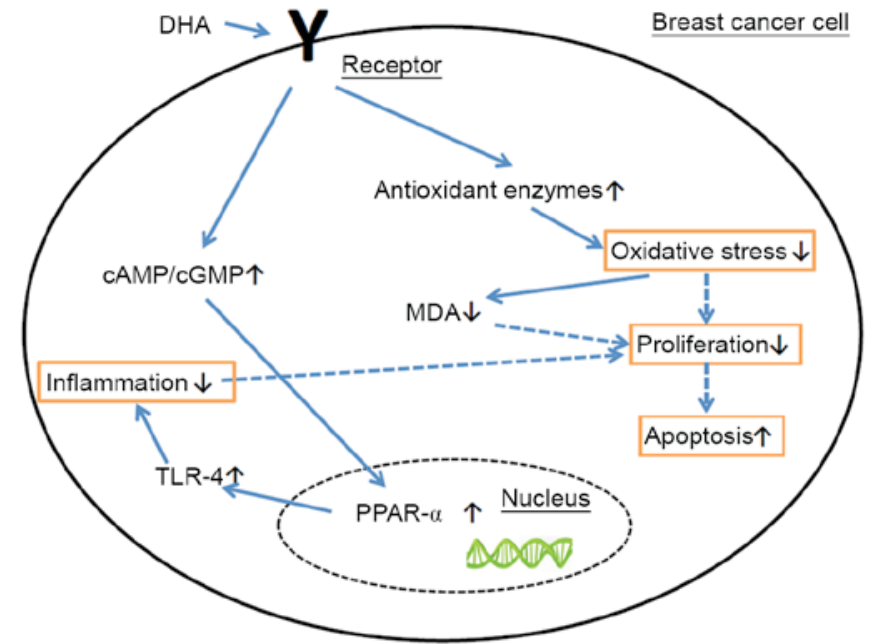

Figure 4. Apoptosis mechanism of DHA. DHA induced the levels of SOD, CAT, and GSH-PX and decreased the concentration of MDA in the BC tissues. DHA increased the ratio of $\mathrm{cAMP} / \mathrm{cGMP}$ levels and promoted the expression of TLR-4 and PPAR- $\alpha$, in order to induce the apoptosis of BC cells. DHA, docosahexaenoic acid; PPAR, peroxisome proliferator activated receptor; TLR-4, Toll-like receptor 4; CAT, catalase; MDA, malondialdehyde; cAMP, cyclic AMP; cGMP, cyclic GMP.

pivotal roles in the development of clinical conditions like cancers (55) and metabolic syndrome (56). Nonetheless, the underlying molecular signaling pathways associating inflammation, oxidative stress and BC cell death are not well defined.

TLR-4 is an important member of the Toll-like receptor family that are exogenous or endogenous ligands, and activate the nuclear factor (NF)- $\kappa \mathrm{B}$ signal transduction pathway and the transcription of the early inflammatory cytokine genes. Ahmed et al (57) demonstrated that lipopolysaccharide, the TLR-4 agonist, enhances 4T1 tumor growth and migration, by increasing the rate of angiogenesis, vascular invasiveness, and tumor invasion. This effect is more evident in TLR-4 $4^{-/}$mice, suggesting that TLR-4 on host immune cells may serve an essential role in inhibiting BC genesis and tumor metastasis (58). TLR4 exerts both a defensive role at the host level and a negative role at the cancer cell level in this murine metastatic breast tumor model (58). Other data suggested that the TLR-4 agonist may induce pro- or anti-tumorigenic effects (57-60). The results in the present study revealed that TLR-4 was highly expressed in the $\mathrm{BC}$ tissue of the $100 \mu \mathrm{g} / \mathrm{ml}$ DHA treatment group. In the BC tissue, TLR-4 was localized in the cell membrane and cytoplasm, similar to that observed by Yang et al (61). The expression of TLR-4 in the cytoplasm may be due to the presence of BC with lymph node metastasis. Thus, this suggests that TLR-4 participates in the generation of BC and DHA upregulated TLR-4 to induce the apoptosis of BC. The expression of TLR-4 was significantly reduced when DHA was at $200 \mu \mathrm{g} / \mathrm{ml}$, this may be due to the fact that different concentrations of DHA use different signaling pathways in breast cancer. The low concentrations DHA $(100 \mu \mathrm{g} / \mathrm{ml})$ stimulated the expression of TLR-4 to induce the apoptosis of BC. However, high concentrations DHA $(200 \mu \mathrm{g} / \mathrm{ml})$ decreased the expression of TLR-4 signaling molecules to promote the $\mathrm{BC}$ tissue apoptosis thoroughly. 
PPAR- $\alpha$, a nuclear transcription receptor, belongs to the PPAR family, and regulates the expression of numerous genes and proteins (62). Activation of PPAR- $\alpha$ has been reported to serve an important role in glucose homeostasis, fatty acid oxidation, lipid metabolism and the inflammatory process (63). The activation of PPAR- $\alpha$ was demonstrated to block the transcription of $\mathrm{NF}-\kappa \mathrm{B}$ and activator protein-1 signaling pathways (62-64). Previously, PPAR- $\alpha$-specific agonists have been reported to inhibit the proliferation of various cancer cells in cultured cell lines and in engraft nude mouse models (65-70). Yessoufou et al (71) revealed that TLR-4 mutant mice exhibited significantly higher PPAR- $\alpha$ expression levels following a methionine/choline-deficient diet, while levels in wild types did not change. This suggests that high expression levels of TLR-4 increase the expression of PPAR- $\alpha$. However, little is known regarding the molecular and cellular mechanisms of PPAR- $\alpha$-mediated growth inhibition of cancer cells. In the present study, it was demonstrated that DHA promoted the expression of PPAR- $\alpha$ and we hypothesized that DHA regulates the glycolipid metabolic pathways in $\mathrm{BC}$ tissues, thus leading to the apoptosis of $\mathrm{BC}$ cells.

In conclusion, DHA induced the activities of SOD, CAT and GSH-PX, and decreased the concentration of MDA in the BC tissues. Furthermore, DHA significantly increased the ratio of $\mathrm{cAMP} / \mathrm{cGMP}$ levels, and promoted the expression of TLR-4 and PPAR- $\alpha$, in order to induce the apoptosis of BC cells (Fig. 4). DHA may be used as a dietary treatment or for prevention of $\mathrm{BC}$ in the future.

\section{Acknowledgements}

The present study was supported by The National Natural Science Fund of China (grant no. 81401189), the Chancellor Hong Boze Fund of Jinzhou Medical College (grant no. XZJJ20130101-03) and The Natural Science Foundation of Liaoning Province (grant no. 20170540385).

\section{References}

1. Meadus WJ, Turner TD, Dugan ME, Aalhus JL, Duff P, Rolland D, Uttaro B and Gibson LL: Fortification of pork loins with docosahexaenoic acid (DHA) and its effect on flavour. J Anim Sci Biotechnol 4: 46, 2013.

2. Opperman M, Marais de W and Spinnler Benade AJ: Analysis of omega-3 fatty acid content of South African fish oil supplements. Cardiovasc J Afr 22: 324-329, 2011.

3. DeSantis C, Ma J, Bryan L and Jemal A: Breast cancer statistics, 2013. CA Cancer J Clin 64: 52-62, 2014.

4. Murff HJ, Shu XO, Li H, Yang G, Wu X, Cai H, Wen W, Gao YT and Zheng W: Dietary polyunsaturated fatty acids and breast cancer risk in Chinese women: A prospective cohort study. Int J Cancer 128: 1434-1441, 2011.

5. Blanckaert V, Kerviel V, Lépinay A, Joubert-Durigneux V, Hondermarck $H$ and Chénais B: Docosahexaenoic acid inhibits the invasion of MDA-MB-231 breast cancer cells through upregulation of cytokeratin-1. Int J Oncol 46: 2649-2955, 2015.

6. Liu J and Ma DW: The role of n-3 polyunsaturated fatty acids in the prevention and treatment of breast cancer. Nutrients 6 : $5184-5223,2014$

7. Mouradian M, Kikawa KD, Dranka BP, Komas SM, Kalyanaraman B and Pardini RS: Docosahexaenoic acid attenuates breast cancer cell metabolism and the Warburg phenotype by targeting bioenergetic function. Mol Carcinog 54: 810-820, 2015.

8. Xue M, Wang Q, Zhao J, Dong L, Ge Y, Hou L, Liu Y and Zheng Z: Docosahexaenoic acid inhibited the Wnt/ $\beta$-catenin pathway and suppressed breast cancer cells in vitro and in vivo. J Nutr Biochem 25: 104-110, 2014.
9. Rahman MM, Veigas JM, Williams PJ and Fernandes G: DHA is a more potent inhibitor of breast cancer metastasis to bone and related osteolysis than EPA. Breast Cancer Res Treat 141: 341-352, 2013.

10. Lijing G, Xingyuan Q, Zhuping S, Jialing G, Bing L, et al: Research progress in the tumor suppression mechanisms of marine polyunsaturated fatty acids DHA. Sci Technol Food Industry 22: 385-391, 2013.

11. Klaunig JE and Kamendulis LM: The role of oxidative stress in carcinogenesis. Annu Rev Pharmacol Toxicol 44: 239-267, 2004.

12. Khan MA, Tania M, Zhang DZ and Chen HC: Antioxidant enzymes and cancer. Chin J Cancer Res 22: 87-92, 2010.

13. Arsova-Sarafinovska Z, Eken A, Matevska N, Erdem O, Sayal A, Savaser A, Banev S, Petrovski D, Dzikova S, Georgiev V, et al: Increased oxidative/nitrosative stress and decreased antioxidant enzyme activities in prostate cancer. Clin Biochem 42: 1228-1235, 2009.

14. De Craemer D, Pauwels M, Hautekeete M and Roels F: Alterations of hepatocellular peroxisomes in patients with cancer. Catalase cytochemistry and morphometry. Cancer 71: 3851-3858, 1993.

15. Elchuri S, Oberley TD, Qi W, Eisenstein RS, Jackson Roberts L, Van Remmen H, Epstein CJ and Huang TT: CuZnSOD deficiency leads to persistent and widespread oxidative damage and hepatocarcinogenesis later in life. Oncogene 24: 367-380, 2005.

16. Jeon SH, Park JH and Chang SG: Expression of antioxidant enzymes (Catalase, superoxide dismutase, and glutathione peroxidase) in human bladder cancer. Korean J Urol 48: 921-926, 2007.

17. Kasapović J, Pejić S, Todorović A, Stojiljković V and Pajović SB: Antioxidant status and lipid peroxidation in the blood of breast cancer patients of different ages. Cell Biochem Funct 26: 723-730, 2008

18. Sharma A, Tripathi M, Satyam A and Kumar L: Study of antioxidant levels in patients with multiple myeloma. Leuk Lymphoma 50: 809-815, 2009.

19. Chung-man Ho J, Zheng S, Comhair SA, Farver C and Erzurum SC: Differential expression of manganese superoxide dismutase and catalase in lung cancer. Cancer Res 61: 8578-8585, 2001.

20. Khan MA, Chen HC, Wan XX, Tania M, Xu AH, Chen FZ and Zhang DZ: Regulatory effects of resveratrol on antioxidant enzymes: A mechanism of growth inhibition and apoptosis induction in cancer cells. Mol Cells 35: 219-225, 2013.

21. Xingyuan Q, Lijing G, Weijie C, Mengyi S, Bing L, et al: Optimized detection methods of fatty acids in the Bohai seaweed by response surface method. Feed Res 1: 65-70, 2015.

22. Ge M, Chi X, Zhang A, Luo G, Sun G, Xie H and Hei Z: Intestinal NF-E2-related factor-2 expression and antioxidant activity changes in rats undergoing orthotopic liver autotransplantation. Oncol Lett 6: 1307-1312, 2013.

23. Yagi K: Simple assay for the level of total lipid peroxides in serum or plasma. Methods Mol Biol 108: 101-106, 1998.

24. Gutiérrez-Salinas J, García-Ortíz L, Morales González JA, Hernández-Rodríguez S, Ramírez-García S, Núñez-Ramos NR and Madrigal-Santillán E: In vitro effect of sodium fluoride on malondialdehyde concentration and on superoxide dismutase, catalase, and glutathione peroxidase in human erythrocytes. ScientificWorldJournal 2013: 864718, 2013.

25. Johnson K, Bruder ED and Raff H: Adrenocortical control in the neonatal rat: ACTH- and cAMP-independent corticosterone production during hypoxia. Physiol Rep 1: e00054, 2013.

26. Thumova M, Pech V, Froehlich O, Agazatian D, Wang X, Verlander JW, Kim YH and Wall SM: Pendrin protein abundance in the kidney is regulated by nitric oxide and cAMP. Am J Physiol Renal Physiol 303: F812-F820, 2012.

27. Geng L and Li Q: Expression and function of heregulin-alpha and its receptors in mammary gland of mouse. Sci China Life Sci 53: 1015-1024, 2010.

28. Geng L, Zhou W, Qu X, Chen W, Li Y, Liu C, Sun J, Yu X, Wang $\mathrm{H}$, Zhang Z, et al: Optimization of the preparation of pectin from aloe using a box-behnken design. Carbohydrate Polymers 105: 193-199, 2014.

29. Ghoneum MH, Badr El-Din NK, Abdel Fattah SM, Pan D and Tolentino L: Hydroferrate fluid, MRN-100, provides protection against chemical-induced gastric and esophageal cancer in Wistar rats. Int J Biol Sci 11: 295-303, 2015.

30. Deepalakshmi K, Mirunalini S, Krishnaveni M and Arulmozhi V: In vitro and in vivo antioxidant potentials of an ethanolic extract of Ganodermalucidum in rat mammary carcinogenesis. Chin J Nat Med 11: 621-627, 2013. 
31. Periyasamy K, Baskaran K, Ilakkia A, Vanitha K, Selvaraj S and Sakthisekaran D: Antitumor efficacy of tangeretin by targeting the oxidative stress mediated on 7,12-dimethylbenz (a) anthracene-induced proliferative breast cancer in Sprague-Dawley rats. Cancer Chemother Pharmacol 75: 263-272, 2015.

32. Giorgio M, Trinei M, Migliaccio E and Pelicci PG: Hydrogen peroxide: A metabolic by-product or a common mediator of ageing signals? Nat Rev Mol Cell Biol 8: 722-728, 2007.

33. Kowaltowski AJ, Castilho RF and Vercesi AE: Mitochondrial permeability transition and oxidative stress. FEBS Lett 495 $12-15,2001$.

34. Martinez-Useros J and Garcia-Foncillas J: Obesity and colorectal cancer: Molecular features of adipose tissue. J Transl Med 14: 21, 2016.

35. Piazza GA, Thompson WJ, Pamukcu R, Alila HW, Whitehead $\mathrm{CM}$, et al. Exisulind, a novel proapoptotic drug, inhibits rat urinary bladder tumorigenesis. Cancer Res. 2001;61:39613968.

36. Kool M, de Haas M, Scheffer GL, Scheper RJ, van Eijk MJ, et al. Analysis of expression of cMOAT (MRP2), MRP3, MRP4, and MRP5, homologues of the multidrug resistance-associated protein gene (MRP1), in human cancer cell lines. Cancer Res. 1997;57:3537-3547.

37. Drees M, Zimmermann R, Eisenbrand G. 3',5'-Cyclic nucleotide phosphodiesterase in tumor cells as potential target for tumor growth inhibition. Cancer Res. 1993;53:3058-3061.

38. Ciardiello F, Pepe S, Bianco C, Baldassarre G, Ruggiero A, et al. Down-regulation of RI alpha subunit of cAMP-dependent protein kinase induces growth inhibition of human mammary epithelial cells transformed by c-Ha-ras and c-erbB-2 protooncogenes. Int. J. Cancer. 1993;53:438-443. doi: 10.1002/ ijc. 2910530315.

39. Singer AL, Sherwin RP, Dunn AS, Appleman M.M. Cyclic nucleotide phosphodiesterases in neoplastic and nonneoplastic human mammary tissues. Cancer Res. 1976;36:60-66.

40. Cohen LA, Straka D, Chan PC. Cyclic nucleotide phosphodiesterase activity in normal and neoplastic rat mammary cells grown in monolayer culture. Cancer Res. 1976;36:2007-2012.

41. Tinsley H.N., Gary B.D., Keeton A.B., Zhang W., Abadi A.H., Reynolds R.C., Piazza G.A. Sulindac sulfide selectively inhibits growth and induces apoptosis of human breast tumor cells by phosphodiesterase 5 inhibition, elevation of cyclic GMP, and activation of protein kinase G. Mol. Cancer Ther. 2009;8:3331-3340. doi: 10.1158/1535-7163.MCT-09-0758.

42. Deguchi A, Thompson WJ, Weinstein IB Activation of protein kinase $\mathrm{G}$ is sufficient to induce apoptosis and inhibit cell migration in colon cancer cells. Cancer Res. 2004;64:3966-3973. doi: 10.1158/0008-5472.CAN-03-3740.

43. Carlson CC, Smithers SL, Yeh KA, Burnham LL, Dransfield DT Protein kinase A regulatory subunits in colon cancer. Neoplasia. 1999;1:373-378.

44. Tinsley, H.N.; Gary, B.D.; Keeton, A.B.; Zhang, W.; Abadi, A.H.; Reynolds, R.C.; Piazza, G.A. Sulindac sulfide selectively inhibits growth and induces apoptosis of human breast tumor cells by phosphodiesterase 5 inhibition, elevation of cyclic GMP, and activation of protein kinase G. Mol. Cancer Ther. 2009, 8 , 3331-3340. doi: 10.1158/1535-7163.MCT-09-0758.

45. DeRubertis FR, Craven PA. Sequential alterations in the hepatic content and metabolism of cyclic AMP and cyclic GMP induced by DL-ethionine: Evidence for malignant transformation of liver with a sustained increase in cyclic AMP. Metabolism. 1976;25:1611-1625. doi: 10.1016/00260495(76)90114-1.

46. Lerner A, Epstein PM. Cyclic nucleotide phosphodiesterases as targets for treatment of haematological malignancies. Biochem. J. 2006;393:21-41. doi: 10.1042/BJ20051368

47. Zhang L, Murray F, Zahno A, Kanter JR, Chou D, et al. Cyclic nucleotide phosphodiesterase profiling reveals increased expression of phosphodiesterase 7B in chronic lymphocytic leukemia. Proc. Natl. Acad. Sci. USA. 2008;105:19532-19537. doi: 10.1073/ pnas.0806152105.

48. Marko D, Pahlke G, Merz KH, Eisenbrand G. Cyclic 3',5'-nucleotide phosphodiesterases: Potential targets for anticancer therapy. Chem. Res. Toxicol. 2000;13:944-948. doi: 10.1021/ tx0000901.

49. Aleksijevic A, Lang JM, Giron C, Stoclet JC, Mayer S, et al. Alterations of peripheral blood lymphocyte cyclic AMP and cyclic GMP in untreated patients with hodgkin's disease. Clin. Immunol. Immunopathol. 1983;26:398-405. doi: 10.1016/00901229(83)90124-1.
50. Aleksijevic A, Lugnier C, Giron C, Mayer S, Stoclet JC, et al. Cyclic AMP and cyclic GMP phosphodiesterase activities in Hodgkin's disease lymphocytes. Int. J. Immunopharmacol. 1987;9:525-531. doi: 10.1016/0192-0561(87)90119-6.

51. Heinonen PK, Metsa-Ketela T. Prostanoids and cyclic nucleotides in malignant and benign ovarian tumors. Med. Oncol. Tumor Pharmacother. 1988;5:11-15.

52. Pertuit M, Barlier A, Enjalbert A, Gérard C. Signalling pathway alterations in pituitary adenomas: Involvement of Gsalpha, cAMP and mitogen-activated protein kinases. J. Neuroendocrinol. 2009;21:869-877. doi: 10.1111/j.13652826.2009.01910.x.

53. Michalides, R.; Griekspoor, A.; Balkenende, A.; Verwoerd, D.; Janssen, L.; Jalink, K.; Floore, A.; Velds, A.; van't Veer, L.; Neefjes, J. Tamoxifen resistance by a conformational arrest of the estrogen receptor alpha after PKA activation in breast cancer. Cancer Cell 2004, 5, 597-605.

54. Shacter E and Weitzman SA: Chronic inflammation and cancer. Oncology (Williston Park) 16: 217-26, 229-232, 2002.

55. Khansari N, Shakiba Y and Mahmoudi M: Chronic inflammation and oxidative stress as a major cause of age-related diseases and cancer. Recent Pat Inflamm Allergy Drug Discov 3: 73-80, 2009.

56. Toyoshi I, Noriyuki S and Yasutaka M: Bilirubin as an important physiological modulator of oxidative stress and chronic inflammation in metabolic syndrome and diabetes: A new aspect on old molecule. Diabetology International 7: 338-341, 2016.

57. Ahmed A, Redmond HP and Wang JH: Links between Toll-like receptor 4 and breast cancer. Oncoimmunology 2: e22945, 2013.

58. Ahmed A, Wang JH and Redmond HP: Silencing of TLR4 increases tumor progression and lung metastasis in a murine model of breast cancer. Ann Surg Oncol 20 (Suppl 3): S389-S396, 2013.

59. Mai CW, Kang YB and Pichika MR: Should a Toll-like receptor 4 (TLR-4) agonist or antagonist be designed to treat cancer? TLR-4: Its expression and effects in the ten most common cancers. Onco Targets Ther 6: 1573-1587, 2013.

60. Ghochikyan A, Pichugin A, Bagaev A, Davtyan A, Hovakimyan A, Tukhvatulin A, Davtyan H, Shcheblyakov D, Logunov D, Chulkina M, et al: Targeting TLR-4 with a novel pharmaceutical grade plant derived agonist, Immunomax ${ }^{\circledR}$ as a therapeutic strategy for metastatic breast cancer. J Trans Med 12: 322, 2014

61. Yang H, Wang B, Wang T, Xu L, He C, Wen H, Yan J, Su H and Zhu X: Toll-like receptor 4 prompts human breast cancer cells invasiveness via lipopolysaccharide stimulation and is overexpressed in patients with lymph node metastasis. PLoS One 9: e109980, 2014

62. Delerive P, De Bosscher K, Besnard S, VandenBerghe W, Peters JM, Gonzalez FJ, Fruchart JC, Tedgui A, Haegeman G and Staels B: Peroxisome proliferator-activated receptor a negatively regulates the vascular inflammatory gene response by negative cross-talk with transcription factors NF-kappaB and AP-1. J Biol Chem 274: 32048-32054, 1999.

63. Peters JM, Shah YM and Gonzalez FJ: The role of peroxisome proliferator-activated receptors in carcinogenesis and chemoprevention. Nat Rev Cancer 12: 181-195, 2012.

64. Takeda S, Ikeda E, Su S, Harada M, Okazaki H, Yoshioka Y, Nishimura H, Ishii H, Kakizoe K, Taniguchi A, et al: $\Delta$ (9)-THC modulation of fatty acid 2-hydroxylase (FA2H) gene expression: Possible involvement of induced levels of PPARa in MDA-MB-231 breast cancer cells. Toxicology 326: 18-24, 2014.

65. Schoonjans K, Staels B and Auwerx J: The peroxisome proliferator activated receptors (PPARS) and their effects on lipid metabolism and adipocyte differentiation. Biochim Biophys Acta 1302: 93-109, 1996.

66. Desvergne B and Wahli W: Peroxisome proliferator-activated receptors: Nuclear control of metabolism. Endocr Rev 20: 649-688, 1999.

67. Shigeto T, Yokoyama Y, Xin B and Mizunuma H: Peroxisome proliferator-activated receptor alpha and gamma ligands inhibit the growth of human ovarian cancer. Oncol Rep 18: 833-840, 2007.

68. Drukala J, Urbanska K, Wilk A, Grabacka M, Wybieralska E, Del Valle L, Madeja Z and Reiss K: ROS accumulation and IGF-IR inhibition contribute to fenofibrate/PPARalpha-mediated inhibition of glioma cell motility in vitro. Mol Cancer 9: 159, 2010 . 
69. Grabacka M, Plonka PM, Urbanska K and Reiss K: Peroxisome proliferator-activated receptor alpha activation decreases metastatic potential of melanoma cells in vitro via down-regulation of Akt. Clin Cancer Res 12: 3028-3036, 2006.

70. Zhou J, Zhang S, Xue J, Avery J, Wu J, Lind SE and Ding WQ: Activation of peroxisome proliferator-activated receptor $\alpha$ $($ PPAR $\alpha)$ suppresses hypoxia-inducible factor-1 $\alpha$ (HIF-1 $\alpha$ ) signaling in cancer cells. J Biol Chem 287: 35161-35169, 2012.
71. Yessoufou A1, Atègbo JM, Attakpa E, Hichami A, Moutairou K, Dramane KL and Khan NA: Peroxisome proliferator-activated receptor-alpha modulates insulin gene transcription factors and inflammation in adipose tissues in mice. Mol Cell Biochem 323: 101-111, 2009.

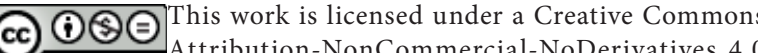
cc) Attribution-NonCommercial-NoDerivatives 4.0 International (CC BY-NC-ND 4.0) License. 